\title{
The Muslim Emigration in Western Anatolia
}

L'émigration musulmane de 1914 en Anatolie occidentale

\section{Elçin Macar}

\section{OpenEdition}

\section{Journals}

Electronic version

URL: https://journals.openedition.org/ceb/922

DOI: $10.4000 /$ ceb.922

ISSN: 2261-4184

\section{Publisher}

INALCO

\section{Printed version}

Date of publication: 9 January 2012

ISSN: 0290-7402

\section{Electronic reference}

Elçin Macar, "The Muslim Emigration in Western Anatolia", Cahiers balkaniques [Online], 40 | 2012,

Online since 27 May 2012, connection on 06 July 2021. URL: http://journals.openedition.org/ceb/922 ; DOI: https://doi.org/10.4000/ceb.922

This text was automatically generated on 6 July 2021.

\section{(c) (†) \&)}

Cahiers balkaniques est mis à disposition selon les termes de la Licence Creative Commons Attribution - Pas d'Utilisation Commerciale 4.0 International. 


\title{
The Muslim Emigration in Western Anatolia
}

\author{
L'émigration musulmane de 1914 en Anatolie occidentale
}

Elçin Macar

1 One major outcome of the Balkan Wars was displacement of populations in large numbers. The Ottoman Empire had known refugees since the Ottoman-Russian War of 1877-1878, but this was a new experience particularly for other Balkan states. Now, the region discovered a new concept: Ethnic cleansing ${ }^{1}$. States looking to homogenize their population did this in two ways: either by treaty or by force.

2 In 1913 the Ottoman Empire signed population exchange treaties with Bulgaria and Serbia. After the one with Bulgaria, about 45,000 Muslims from Bulgaria came within the new borders of the Ottoman Empire and about the same number of Bulgarians migrated to Bulgaria ${ }^{2}$. Following the loss of the Balkans, Ottoman intellectuals turned their eyes to Anatolia. This was the only territory the Empire retained and densely populated with Turks. The period was parallel with the coup d'état of the CUP (Committee of Union and Progress). Officers from CUP, most of whom were Macedonians, had personally observed that their homeland, including the cities where they had been raised, were lost, which was a major trauma for them. The period is a watershed in Ottoman politics, while the 'Ottomanism' policies for keeping the subjects of the empire together was simply replaced by those of 'Turkism'.

3 By the second stage of the CUP, changes were seen in the usual imperial policies. Instead of just classifying the population in terms of religion, they started now to subdivide the 'Muslim' category by ethnicity as well. Population statistics thus became one of the political instruments of the government and then started the "ethnicity engineering"3. 


\section{Ridding the country of " internal ennemies"}

4 Among Anatolian Christians, Ottoman Greeks were the first target of the CUP who feared losing the "last remaining territory". Talat Pasha, Minister of the Interior, talked to German diplomats about ridding the country of "internal enemies". He was more concerned about population being displaced as a result of the war than he was about the fronts themselves. Halil Menteşe, President of Parliament, wrote about Talat Pasha in his memoirs: "His priority was cleansing the homeland of elements whose treason was revealed during the Balkan War". And he summarized how that policy was implemented: "The Ottoman Greeks will be frightened"

5 Mahmut Celal Bey (Bayar) ${ }^{5}$, the secretary of the CUP in Smyrna, described in his memoirs the policy towards the Ottoman Greeks as a "reciprocal national act" and said that it appeared as a response to what Muslims went through in the Balkans. The point, he explained, was "to eliminate non-Turk masses gathered in strategic plots who were bound to external negative influences". Fuat Dündar interprets deportation of the Ottoman Greeks in 1914 as revenge for the Balkan wars. And with reference to the policy of replacing non-Muslims with Muslims, Mehmet Faik Bey, the MP from Edirne, said "We have learned forced emigration from our neighbours".

6 The Aegean, which was the main focus of the Megali Idea as well, was the first arena for such policy, which had two goals: 1- Procuring space for the coming immigrants: 2After the traumatic loss of the Balkans, homogenizing the population in order to keep Anatolia in hand.

7 They used two methods to force the Ottoman Greeks to leave:

- intimidating, terrorizing and threatening, in a few places even killing;

- placing Muslim immigrants in the villages where Ottoman Greeks were living, and having these immigrants drive the Ottoman Greeks away.

8 A remark about another group is necessary here: the nomadic Turkmen. The CUP implemented similar policies, particularly in the Aegean and Mediterranean, to force nomadic groups to settle.

9 In 1913 the government issued regulations for the immigrants (Muhacirin Nizamnamesi), a set of rules for the settlement of migrants from the Balkans. Regions where the Turkish population had decreased were given priority. It started with the Thrace and Edirne, followed by Smyrna and Balikesir. The aim was to reinforce regions where the Muslim population had thinned as a result of the wars, such as the Dardanelles and the area around them. State land around the Ottoman Greek villages were assigned first for this purpose, then the villages themselves were confiscated.

10 The government provided stock as a substitute for the immigrants who lost theirs because of plague. Construction materials were usually supplied by the government, while lumber was provided from state forests for once. The immigrants were granted tax immunity temporarily and they were exempted from fiscal obligations for two years.

11 In fact, two categories of people arrived. The immigrants were people displaced within the framework of the treaties, whereas the refugees were the ones displaced because of massacres, oppression and intimidation. The refugees were generally assigned to temporary settlements, since the government thought they might one day go back to 
their own countries once the situation improved or, more likely, a bilateral agreement was reached.

Single immigrants were not given housing. The immigrants had to apply to the police for an Ottoman identification within 15 days. Settlement costs for the immigrants were covered by the Navy Society, which collected donations from the Ottoman Greeks by force. The Red Crescent helped with the costs as well. As yet no legal measures were taken to provide estates and lands for the immigrants, which would not occur until 1916. As a result, there were some inconsistent and arbitrary practices until that date. The immigrants were first placed in quarantine for contagious diseases and the doctors who examined them every three days prepared reports. Nevertheless, as a result of their living conditions various diseases broke out among the immigrants, particularly cholera.

Immigrants were obliged to settle wherever they were sent. Although the regulations permitted them to purchase land with their own money if approved, settlement policy ruled this out during World War I.

Immigrants were exempted from military service for six years. When World War I broke out, however, those who arrived and registered before the Balkan Wars were conscripted. The rest were not called up "for now".

The Office of Tribal and Refugee Settlement (Aşair ve Muhacirin Müdüriyet-i Umumiyesi) was responsible for the settlement of Muslim immigrants, but from time to time governors and district officials stepped in as well.

16 Most of the population in and around Smyrna that came after the Balkan Wars was from Macedonia and Kosovo. A commission was formed for settlements in Smyrna and deputy governor Kemal Bey was appointed head. Immigrants were gathered in Smyrna and from there, some were transferred to Aydın, Manisa and Menteşe ${ }^{6}$. Schools and mosques were used as temporary shelters.

Pressure on the Ottoman Greeks in the Aegean increased from March 1914. Muslim immigrants were settled along a route from the coast to the interior. Strict supervision from the center was apparent because, whenever an unapproved settlement occurred, the center intervened and ordered evacuation.

The 'maximum 10\%' rule was applied to the Albanian and Bosnian immigrants. On 3 February 1914, the Ministry of the Interior announced that those from Kosovo and Bitola who resided in Smyrna should apply to the police for registration, or they would be deported. After 1914, Albanians were forbidden to settlel in Western Anatolia. Apparently, Muslim immigrants to the country were classified according to their ethnicity, settlement regulations were issued for almost every group and some were banned from settling in some regions. The statistics show that 'the main element' was Turkish? ${ }^{7}$.

19 The government requested all the provinces to determine which land was empty. While arable land decreased during the settlement process, demand for the land left by the Ottoman Greeks and Armenians increased on the part of both the government and the immigrants. The new immigrants first looted goods left by the Ottoman Greeks. Then, commissions were formed and those goods were collected officially. In 1914, the parliament authorized the Ministry of Interior to use the income from goods that once belonged to Ottoman Greeks in Aydın, which was to be used to build schools and for various other activities. 

were named after sultans, such as Sultaniye, Reşadiye, Aziziye, Hamidiye. But with the advent of World War I, these construction activities were stopped. In 1915, village construction for Balkan immigrants cost 15 million liras, which amounted to a quarter of the total budget.

According to the regulations, the sort of land and climate to which the immigrants were accustomed should be taken into consideration in settling them. This precept proved impractical and was abandoned after the war. Evidence shows that the immigrants were not classified by agricultural experience or skills. The dissimilarity of the Muslims in the regions where they were settled caused a decline in agricultural production. This affected olive production in particular. The newcomers lacked expertise. Hilmi Bey, district officer (kaymakam) of Çeşme put the population in 1914 at 45,000 , Ottoman Greeks accounting for 40,000 of these. He attributed the Greek migration to "psychological fear", and added that Muslim immigrants, who came from a harsh climate, were not suitable for Çeşme's climate and lacked the requisite agricultural knowledge and skills.

"For instance, there were some who saw anise for the first time and because they didn't

know any better, some even tried to feed the animals with it"8.

According to Talat Pasha, the CUP benefited from the expulsion of Muslims from Balkan countries, for it accelerated the Islamification of Anatolia. For instance, a document was sent to the Consulate of Thessaloniki asking for skilled Muslim immigrants from the region for Anatolia.

\section{Both Venizelos and the CUP favored a population exchange}

On 20 May 1914, Galip Kemali Bey, the Ottoman ambassador to Athens proposed a population exchange to Venizelos. The exchange delegation gathered in Smyrna in 1914 and suggested exchanging the Muslims in Macedonia and Epirus with the Ottoman Greeks in Smyrna, within 30 kilometers of the coast.

During the exchange attempt of 1914, they decided to settle the immigrants from Macedonia in the Ottoman Greek villages and to employ the gendarmerie for security, since forming a commission for the exchange would take time. Within the framework of the agreement with Venizelos, in a document that predates World War I, the Directorate of General Security (Emniyet-i Umumiye) sent a telegram to Aydın Province, ordering them "not to settle Muslim immigrants in the Ottoman Greek villages who are not from Greek administrative regions". Documents also show that the treatment of the Ottoman Greeks somehow softened once negotiations with Greece began.

By May 1914, about 100,000 immigrants had arrived. They were ordered to settle in the Ottoman Greek villages, accompanied by the gendarmerie. Any immigrant who resisted was to be arrested. During the first three weeks of June, three shiploads of immigrants arrived. They were transferred to Çeşme ve Kato Panaia, which 45,000 Ottoman Greeks had to leave. In mid-June these operations were halted after a protest from Greece, but as a result of unsettled immigrants, operations resumed in July.

Venizelos's main concern was to convince the CUP to accept the annexation of the islands. But when that plan failed and the war broke out, the population exchange

Cahiers balkaniques, 40 | 2012 
project was interrupted and the commission that had been formed to this end became a commission of "property exchange".

In July and August, an inventory of population, professions and properties was drawn up after the Ottoman Greeks had fled. The idea was to form a 'productive' settlement and to calculate the proportion of remaining Ottoman Greeks.

Emanuilidis, an Ottoman Greek member of parliament, in a speech to parliament on 6 July 1914, stated that 150,000 Ottoman Greeks had left for Greece and that the process which had started as an economic boycott had now become political. Ladas confirms that figure, while Halil Menteşe says it was 200,000 and Celal Bayar 130,000.

The government first justified the migration of Ottoman Greeks as a way of 'encouraging Greeks'. But later on, Talat Pasha correlated the migration to the arrival of immigrants. And anyway, this was caused by the Balkan states.

Emanuilidis asked why the newcomers were settled in the Ottoman Greek villages. Talat Pasha, the Minister of the Interior said that it was "for practical reasons, since the Muslim villages were filled, the Ottoman Greek villages were in line and the government was obliged to do so". When Emanuilidis asked "why they weren't settled in the regions beyond Halep", Talat Pasha said "that would be fatal to them and the government lacked the power to build new immigrant villages" ${ }^{10}$.

31 When the war began in August 1914, the expulsion policy was interrupted. Migration of skilled workers had a negative impact on agricultural production and during the war, this reduced the number of soldiers available to the Greek army. Therefore, Greek citizens were arrested, while Ottoman Greeks were conscripted and sent to labor battalions.

In 1915, the new practice of deporting people to the interior instead of driving them away was introduced: "removing them from the dangerous zones", in other words, and "taking them hostage". According to Ladas, 50,000 Ottoman Greeks were relocated to the interior.

The number of immigrants from the Balkans totalled 413,922, and those that arrived in Aydın province 145,868. The number of immigrants that arrived in 1914 came to about 250,000 . About 115,000 came from Greece. Engin Berber writes that after the Balkan Wars, those who settled only in Bergama, Menemen, Foça and Çeşme came to 53,151. Some Bosnians fleeing Serbs were settled in Ayvalık after the Ottoman Greeks were deported. There were 46,000 people living in Ayvalık in 1912, and in 1919 only 3,500 Ottoman Greeks remained.

\section{Conclusion}

Prior to World War I, Ottoman Greeks were mainly victimized by the Special organization or by gangs, but once the war broke out, the initiative was entirely in the government's hands.

The documents show that the forced emigration of Ottoman Greeks and the settlement of Muslims in the Aegean was coordinated by the CUP secretariat in Smyrna, that is, by Celal Bayar. The transfers and settlements depended on approval by the central government, particularly Talat Pasha himself. Censuses were taken both before and after settlement so that population movements could be followed. Population statistics 
per subdivision of a province were prepared every three months and the composition of population was followed. According to Dündar, between 1913 and 1918, almost half the population of 17.5 million changed places.

Deporting Ottoman Greeks and replacing them with Muslims in 1914 anticipated the 'self-determination' principle mentioned by Wilson a few years later. Making a group the majority in a region would provide legitimacy for them to decide their future.

The CUP not only forcibly relocated immigrants, but also tried to mobilize Balkan Muslims by means of propaganda and by invitation. The expansionist tendencies of the Greek government were at odds with the CUP.

Ayhan Aktar summarized the policy of the CUP as such: "The turkification programme can [...] be defined in practice as a set of policies aimed at establishing the unconditional supremacy of Turkish ethnic identity in nearly all aspects of social and economic life".

But Zafer Toprak takes issue with Aktar's statement. According to Toprak, this amounts to a 'reverse reading' of the Republic of Turkey. Balkan nationalisms contributed to this thesis. He denies that the CUP's education policies and their theoretical accumulation can be interpreted as 'Turkification'. He suggests that Aktar focused too much on the "action" during the war.

Thus, there are various different interpretations of the topic. But the era's worst legacy is the attitude that states have a right to exchange or deport their populations like property. The events that followed the Balkan Wars, when states negotiated and practiced voluntary population exchange, led to the forced population exchange that Turkey and Greece agreed upon in the Lausanne Treaty. That such exchanges were ever portrayed as successful, when in fact they were disastrous for the people involved, proves that history should be interpreted from a humanitarian perspective.

\section{BIBLIOGRAPHY}

Âlım, Tülay, (1988), Balkan Harplerinin Bitimi ile Birinci Dünya Savaşı Arasında Yerel Basına Göre İzmir, (unpublished MA thesis), Izmir: Dokuz Eylül Üniversitesi, Atatürk İlkeleri ve İnkılâp Tarihi Enstitüsü.

Çetin, Nurten, (2004), Osmanlı Arşiv Belgelerine Göre 1914 Osmanl-Yunan Nüfus Mübadelesi Girişimi, (unpublished MA thesis), Istanbul: Yıldız Teknik Üniversitesi, Sosyal Bilimler Enstitüsü.

Dündar, Fuat, (2008), Modern Türkiye'nin şifresi-İttihat ve Terakki'nin Etnisite Mühendisliği (1913-1918) Istanbul: İletişim.

McCarthy, Justin, (1995), Death and Exile: The Ethnic Cleansing of Ottoman Muslims, 1821-1922, Princeton: Darwin Press.

Önder, Selahattin, (2000), “1913 Türk-Bulgar Mübadelesi,” Yeni Türkiye, no. 31, Ocak-şubat. 
Sarısır, Suraiya, (2006), “1913 Türk-Bulgar Mübadele Sözleşmesi”, Askeri Tarih Araştırmaları

Dergisi, sayı: 7 şubat.

Uran, Hilmi, (1959), Hâtıralarım, Ankara.

\section{NOTES}

1. Especially see: McCarthy, Justin, Death and Exile: The Ethnic Cleansing of Ottoman Muslims, 1821-1922, Princeton: Darwin Press, 1995.

2. See: Sarısır, Serdar, "1913 Türk-Bulgar Mübadele Sözleşmesi” Askeri Tarih Araştırmaları Dergisi, sayı: 7, şubat 2006, pp. 55-65; Önder, Selahattin, “1913 Türk-Bulgar Mübadelesi,” Yeni Türkiye, no : 31, Ocak-şubat 2000, pp. 342-346.

3. For details see: Dündar, Fuat, Modern Türkiye'nin şifresi-İttihat ve Terakki'nin Etnisite Mühendisliği (1913-1918), Istanbul: İletişim 2008.

4. Osmanlı Mebusan Meclisi Reisi Halil Menteşe’nin Anıları, Istanbul: Hürriyet Vakfı Yayınları, 1986, p. 166.

5. The third president of the Turkish Republic.

6. For details see: Âlim, Tülay, Balkan Harplerinin Bitimi ile Birinci Dünya Savaşı Arasında Yerel Basına Göre İzmir, (unpublished MA thesis), Istanbul: Dokuz Eylül Üniversitesi, Atatürk İlkeleri ve İnkılâp Tarihi Enstitüsü, 1998.

7. Dündar F., op. cit, p. 165.

8. Uran, Hilmi, 1959, Hâtıralarım, Ankara, p. 72.

9. For Ottoman documents see: Nurten Çetin, Osmanl Arşiv Belgelerine Göre 1914 Osmanl-Yunan Nüfus Mübadelesi Girişimi, (unpublished MA thesis), Istanbul: Yıldız Teknik Üniversitesi, Sosyal Bilimler Enstitüsü, 2004.

10. Dündar, Modern Türkiye'nin şifresi..., op.cit. p. 223.

\section{ABSTRACTS}

With the Balkan Wars, the whole region was introduced to a new concept: Ethnic cleansing. States looking to homogenize their population did this in two ways: either by treaty or by force. Population statistics thus became one political instrument and then started the "ethnic engineering". Among Anatolian Christians, Ottoman Greeks were the first target of the CUP who feared losing the "last remaining territory". Talat Pasha, Minister of the Interior, talked to German diplomats about ridding the country of "internal enemies". After expulsions, terrorism and deportations between 1913 and 1918, on both sides of the Aegean, almost half the population of 17.5 million changed places. The era's worst legacy is the idea that states have a right to exchange or deport their populations like property.

Avec les guerres balkaniques, toute la région apprit à connaître un nouveau concept: le nettoyage ethnique. Les États cherchant à homogénéiser leur population le firent de deux manières : par les traités ou par la force. Les statistiques démographiques devinrent ainsi un instrument politique et commença alors «la manipulation ethnique». Parmi les Chrétiens anatoliens, les Grecs ottomans furent la première cible du CUP qui craignait de perdre «le 
dernier territoire restant ». Talat Pacha, ministre de l'Intérieur parla aux diplomates allemands de débarrasser le pays « des ennemis de l'intérieur ». Expulsions, terreur et déportations : entre 1912 et 1918, sur les deux rives de l'Égée, près de la moitié des 17,5 millions d'habitants ont été « déplacés ». Le legs le pire de cette période est la tendance des États à croire qu'ils ont le droit d'échanger ou de déporter leurs populations comme du bétail.

\section{INDEX}

Geographical index: Balkans, Asie Mineure, Smyrne, Aydin, Cesme, Phocée, Ayvalik

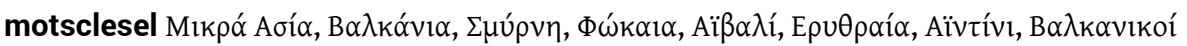

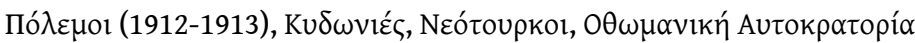

Chronological index: guerres balkaniques (1912-1913), Empire ottoman

Keywords: ethnic cleansing, muhacirs, Talat Pacha (1874-1921), Young Turks, refugees, demographic statistics, Asia Minor, Balkans, Smyrna, Aydin, Deportation, Cesme, Phocaea, Ayvalik, History, Balkan Wars (1912-1913)

Subjects: Histoire

motsclestr Anadolu, Balkanlar, İzmir, Çesme, Foça, Ayvalik, Aydin, Balkan Savaşları (1912-1913), Genç Türkler, Osmanlı İmparatorluğu, Ulusal Kurtuluş Savaşı (1914-1923)

Mots-clés: Jeunes-Turcs, Aşair ve Muhacirin Müdüriyet-i Umumiyesi, Bayar Celal Mahmut (1883-1986), muhacirs, CUP, nettoyage ethnique, Talat Pacha (1874-1921), Kaymakam, Muhacir/ mouhadjir, réfugiés, statistiques démographiques, déportation, Talaat Mehmet Pacha (1874-1921) motsclesmk БАЛКАНОТ, МАЛА АЗИЈА, МЛАДОТУРСКАТА, ОТОМАНСКАТА ИМПЕРИЈА, СМИРНА 